\title{
The Role of Digital Loyalty Program towards Customer Loyalty through a Measure of Satisfaction
}

\author{
Roymon Panjaitan* \\ Department of Business, Faculty of Computer and Business, Universitas Sains dan Teknologi Komputer \\ Jl. Majapahit No.605, Pedurungan Kidul, Semarang, Central Java 50192, Indonesia \\ roymon_panjaitan@yahoo.com
}

Received: $22^{\text {nd }}$ February 2021/ Revised: $06^{\text {th }}$ April 2021/ Accepted: $12^{\text {th }}$ April 2021

How to Cite: Panjaitan, R. (2021). The role of digital loyalty program towards customer loyalty through a measure of satisfaction. The Winners, 22(2), 163-171. https://doi.org/10.21512/tw.v22i2.7082

\begin{abstract}
The research aimed to explore the importance of loyalty programs to customer satisfaction and loyalty in digital business in Indonesia. The concept of theoretical development of the resource-advantage theory of competition and service-dominant logic was used for the development of research findings. Lazada, one of the e-commerce platforms, offered digital loyalty programs such as points store, loyalty store, e-coupon, e-newsletter, and flash sale. Thus data collection was distributed through an online questionnaire to Lazada customers, with a sample size of 384 respondents. Data testing with linear regression analysis was conducted to test the variables of the Lazada digital loyalty program on customer loyalty mediated customer satisfaction. The results shows that in digital loyalty program variables, the program features contribute positively directly and have the success of mediated customer satisfaction in the digital loyalty program. More products that offer customer-oriented technology feature innovation will increase customer loyalty amidst dynamic marketing capabilities in digital business innovation change, which gives impact to managers.
\end{abstract}

Keywords: digital loyalty program, customer satisfaction, customer loyalty

\section{INTRODUCTION}

The growth of digital innovation in Indonesia is coherently diffused by innovation. Dissemination of information technology provides convenience from aspects of digital business, such as marketplaces and e-commerce. The emergence of this industry also encourages the growth of the creative economy in Indonesia. Competition for technical aspects and delivery of services such as website design and responsiveness is part of efforts to increase satisfaction and loyalty. To promote customer retention and discourage the customer from turning to rivals, digitalbased loyalty schemes are intensively introduced by e-commerce.

Raising customer loyalty and loyal customer is a top priority and as one of the vital characteristics in developing and sustaining a key business environment (Iglesias et al., 2020; Mainardes, Rosa, Nossa, 2020; Vildová et al., 2015). Customer satisfaction is considered the main determinant in building and maintaining the main business environment. Good services allow customers to return to the sector or area where orders are often made. Advanced access to new goods, extra discounts, or indeed free items can be included in several bonuses. Usually, clients register their personal details with the organization and obtain a unique ID, such as a numeric ID or ID card as the identifier when making the payment.

Lazada is one of the e-commerce platforms of the latest developments in the digital business, with an average of 135 million visitors by 2020 . The urgency of the problem of the research is whether Lazada has the potential to compete comparatively with digitalbased to maintain customer loyalty. Moreover, the research aims to find out the logical perspective that can be built into new or added value in the Lazada platform since there have been many competitors that dominate in this business. It is considered important to discuss since the growing platform of other digital businesses are oriented to the consumer perspective in e-commerce business competition in particular. Through the concept offered from the digital loyalty relationship on the loyalty customer, the importance of the concept of customer satisfaction can bridge the relationship. Watson et al., (2015) point out that loyalty consists of buying attitudes and behaviors that benefit one seller over a competitor.

Bijmolt et al. (2017), Breugelmans and LiuThompkins (2017), Bruneau, Swaen, and Zidda 
(2018), and Trivedi and Yadav (2020) suggest that loyalty programs are a much more important driver of purchasing behavior than corporate loyalty. Web features are the process of building customer loyalty from trust and distrust to differently mediate customer perceptions (Liu et al., 2017; Ofori, Boakye, \& Narteh, 2018; Seckler et al., 2015; Trivedi \& Yadav, 2020). Thus consumer loyalty through sales programs can be built from the seller's facilities to the consumer perspective.

The understanding of customer loyalty is incomplete, while some research agree that there is a positive link in the success of digital loyalty programs to higher online programs than in the offline market because consumers in the online market are not charged for physical transportation fees (Lim \& Lee, 2015). In addition, the benefits of customer segmentation of consumer preferences are higher, so they provide stronger profit incentives for retailers through loyalty programs (Ieva \& Ziliani, 2017).

Vesel and Zabkar (2009) conclude that in a retail service environment, the level of quality of personal interaction, loyalty programs, and customer satisfaction as important determinants of customer loyalty. However, according to Sungirirai, Chiguvi, and Sungirirai (2017) loyalty programs have a weak effect on customer behavior of economic rewards and exchange options although customer familiarity is already integrated with the program.

Through the member card, a reward scheme can measure the level of satisfaction and intensity of customer loyalty (Li, 2018). Another important point in digital marketing is having value-added attributes to increase customer loyalty from the content attributes, customer service attributes, and appearance features (Khan \& Islam, 2017; Zakaria et al., 2014). This is reinforced from the results by Zakaria et al. (2014) with the object of retail industry research, which also shows that some loyalty programs such as rebate gift vouchers, member's day, and magazine have no significant effect on customer satisfaction. The points that must be collected to redeem gift vouchers are too large compared to the amount of money spent by customers, so customers prefer other companies that offer similar program with easier terms to follow. Therefore, it takes the concept of measurable variables as a bridge to achieve increased customer loyalty.

Considering the inconsistency of previous research findings, the research provides a conceptual model of customer satisfaction relationships as a bridge from the correlation of loyalty design programs to customer loyalty. Other researchers have focused a lot on the relationship of service quality to customer loyalty, but only few researchers discuss digital loyalty programs through concepts that offer digital features such as store points, loyalty stores, e-coupons, e-newsletters, and flash sales. The feature is positively correlated to be an important key part of customer relationship management products to increase customer satisfaction (Hassan et al., 2015). Similarly, the effect of customer satisfaction on loyalty is fully mediated by trust and commitment in the higher education customer segment (Schirmer et al., 2018). The concept of online buying (i.e., website images, online routines, and website knowledge) provides important insights into how e-companies can pursue and use pleasure to highlight customer loyalty. These results enable a better understanding of the specificity of customers with practical actions aimed at their real needs and expectations. This understanding is also supported by Pereira, de Fátima Salgueiro, and Rita (2017) that images, routines, and website knowledge significantly affect e-customer satisfaction.

Customer satisfaction is a conscious evaluation or cognitive assessment concerning whether the performance of a product or service is relatively good or poor, or whether the product or service matches the purpose of use (Alnawas \& Hemsley-Brown, 2018; Alsaggaf \& Althonayan, 2018). It can also be attributed to the extent to which the performance of such products is in line with buyer expectations (Kotler, 2018). The definition of customer loyalty is customer loyalty to continue to use the same product of a company. This may apply solely to the purchase of the same particular brand repeatedly if there is only one available brand, cheapest brand, and so on (Tjiptono \& Chandra, 2011). The definition of a loyalty program can be interpreted as a marketing program to increase customer satisfaction and loyalty by offering similar rewards, and to achieve financial returns such as market share, competitive positions, or recurring purchases, while at the same time collect customer data to do targeted marketing (Breugelmans et al., 2015).

The behavior of internet users can differ considerably from the population in general. This also applies to e-commerce players and their effect on a digital loyalty program. Loyalty programs for a digital business are also usually digital-based where companies can simultaneously build a digital database for e-mail marketing, track customer birthdays, and other special events (Tahal, 2014). Some types of conventional and digital loyalty programs have been summarized in Table 1.

Some research on digital loyalty program has mixed results on customer satisfaction and loyalty. Digital loyalty programs are proven to increase sales but not to generate true loyalty to the company (Nobre \& Rodrigues, 2018). Tahal (2014) shows that 73\% of e-commerce users claim to be happy with loyalty programs, but in reality, only $31 \%$ of users admit to the loyalty program. It raises the question of whether the digital loyalty program has a positive effect on customer satisfaction and customer loyalty. The same research also shows that there is a mismatch between the loyalty program communicated by the company compared to the loyalty program expected by the customer (Tahal, 2014). It results in the loyalty program being untargeted and not achieving the expected goals.

The research focuses on whether the digital loyalty program has good engagement with its 
Table 1 Loyalty Program Conventional vs Digital Loyalty Program

\begin{tabular}{cll}
\hline No & Loyalty Program Conventional (Magatef \& Tomalieh, 2015) & Loyalty Program Digital (Various source) \\
\hline 1 & Points system & Digital Point Program \\
2 & Tier system & Digital Tier program \\
3 & VIP membership & VIP memberships \\
4 & Payback money for loyal customer & Digital payback system \\
5 & Partnerships with other company to provide all-inclusive offers & Partnership program \\
6 & Loyalty Card Program & Social Media Based program \\
7 & Frequent Buyer Program & Gamification program \\
8 & Gift Card or Certificate & Community program \\
9 & Return policy for loyal customer & Subscription program \\
10 & Discount over time or volume of good & Charity Program \\
11 & Bundled Goods & Flash Sale \\
12 & Non-monetary programs & \\
\hline
\end{tabular}

Source: Researcher (2021)

customers and has significant influence on customer satisfaction and customer loyalty. Based on previous research, the hypotheses that can be formed are:

$\mathrm{H}_{1}$ : Digital loyalty program significantly affects customer satisfaction.

$\mathrm{H}_{2}$ : Digital loyalty program significantly affects customer loyalty.

With the help of technology, several types of new loyalty programs can be offered to customers as described in Table 1, such as a gamification system that offers loyalty programs to customers by having to play video games. Besides, there are also loyalty programs based on social media such as, fan pages and community forums. However, some loyalty programs that are proven to be popular are still used, namely point programs, tier programs, membership programs, and payback programs, and flash sale programs. The five types of loyalty programs are most commonly used by digital businesses such as Lazada, which is the e-commerce examined in the research. Based on the development of loyalty program into a digital version, the research is to hypothesize that each of the five digital-based loyalty programs from Lazada has a significant influence on customer satisfaction and loyalty:

$\mathrm{H}_{1 \mathrm{a}}$ : Toko points program significantly affects customer satisfaction.

$\mathrm{H}_{1 b}$ : Store loyalty program significantly affects customer satisfaction.

$\mathrm{H}_{1 \mathrm{c}}$ : E-coupon program significantly affects customer satisfaction.

$\mathrm{H}_{1 \mathrm{~d}}$ : E-newsletter program significantly affects customer satisfaction.

$\mathrm{H}_{1 \mathrm{e}}$ : Flash sale program significantly affects customer satisfaction.
$\mathrm{H}_{2 \mathrm{a}}$ : Toko points program significantly affects customer loyalty.

$\mathrm{H}_{2 b}$ : Store loyalty program significantly affects customer loyalty.

$\mathrm{H}_{2 \mathrm{c}}$ : E-coupon program significantly affects customer loyalty.

$\mathrm{H}_{2 \mathrm{~d}}$ : E-newsletter programs have a significant effect on customer loyalty.

$\mathrm{H}_{2 \mathrm{e}}$ : Flash sale program significantly affects customer loyalty.

The relationship between customer satisfaction and customer loyalty has been proven in previous research. Iddrisu et al. (2015) reveal that customer satisfaction has a direct relationship with customer loyalty judging by the results of the calculation of correlation between customer satisfaction to customer loyalty of 0,763 . Compared to what has been conducted, this research focuses on how the digital loyalty program affects customer satisfaction and customer loyalty. Therefore, the third and fourth hypotheses can be formed:

$\mathrm{H}_{3}$ : Customer satisfaction significantly affects customer loyalty.

$\mathrm{H}_{4}$ : Customer satisfaction has a mediation role between digital loyalty programs and customer loyalty.

Lazada's online business digital media is chosen as the locus of research since the digital program provides its uniqueness for its competitors in the same field in e-commerce. This leads to explore the conceptual model of the function of customer satisfaction in its ability to bridge or improve its relationship to customer loyalty. Therefore, the current research aims to explore further and bridge the research gap in the literature by developing conceptual 
models consisting of the concept of the digital loyalty program, customer satisfaction, and customer loyalty.

\section{METHODS}

Data collection method is conducted by using the online questionnaire method. Distribution of Google Form links by giving some statements to Lazada users. Topics raised in the research are digital loyalty programs, customer satisfaction, and customer loyalty that occur in Lazada company. The target population of the research is Lazada app users with a variety of demographics. The criteria in determining the sample target are: 1) Lazada app users; 2. No transaction on Lazada; and 3) Frequent transaction through Lazada (more than 5 times). The sampling method is purposive sampling where the selected sample has several inclusion criteria by the three criteria. Sampling is shared via social media. Based on the number of Lazada users reaching 10 million users, the minimum number of samples required is 384 samples (Sekaran \& Bougie, 2016).

Statistical analysis used in the research is Statistic Parametric with Multiple Linear Regression Test by testing free variables and mediation variables against bound variables. Before conducting multiple linear regression tests, several tests are conducted in advance such as validity tests and reliability tests to identify the items of the questionnaire. Next, normality test, linearity test, and heteroscedasticity test are conducted as a condition of the feasibility of the linear regression model. A parameter test is conducted to determine the influence of independent variables on dependent variables. Parameter testing includes simultaneous parameter testing ( $\mathrm{F}$ test) and partial parameter testing (t-test). Simultaneous parameter testing (F test) shows whether all independent variables included in the model have a mutual influence on dependent variables. Partial Parameter Testing (t-test) is used to prove whether independent variables individually affect dependent variables. The four steps in using the Causal Step Method are to: 1) Create an independent variable regression equation $(\mathrm{X})$ against a dependent variable $(\mathrm{Y})$; 2) Create an independent variable regression equation (X) against the mediation variable $(\mathrm{M}) ; 3$ ) Create an independent variable regression equation (X) against a dependent variable (Y) by entering a size mediation variable (M); 4) Draw conclusions as to whether the mediation variable mediates perfect mediation or partial mediation.

Variable $M$ is declared as mediation or intervening variable if it meets criteria, namely: 1) If it is in equation $\mathrm{I}$, the independent variable (X) affects the variable that is suspected as the mediation variable (M); 2) If it is in equation II, the independent variable $(\mathrm{X})$ affects the dependent variable (Y); and 3 ) If it is in equation III, the variable that is suspected as the mediation variable (M) affects the dependent variable (Y). The test is conducted using the help of the SPSS program. Figure 1 shows a diagram design of mediation variable regression analysis with causal step method. The test is to prove the significance of each Lazada digital loyalty program (X) to customer satisfaction (M) in shopping at Lazada.

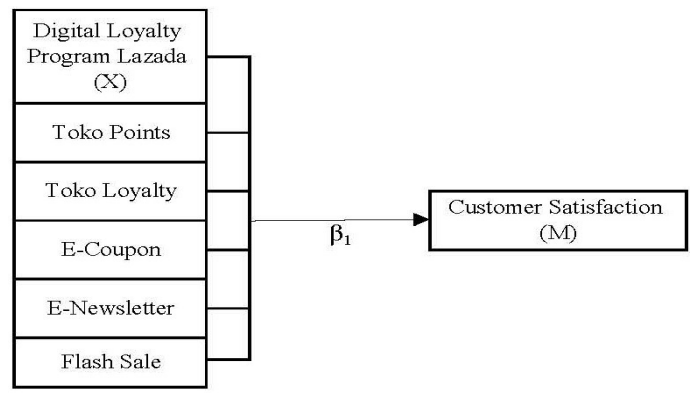

Figure 1 Direct Effect of Variable X on Variable M

The regression equation in the first model is:

$M=\beta_{0}+\beta_{1} X$

Figure 2 shows diagram on the direct influence of the digital loyalty program $(\mathrm{X})$ on customer loyalty (Y). The test aims to prove the significance of each Lazada digital loyalty program to customer loyalty in shopping at Lazada.

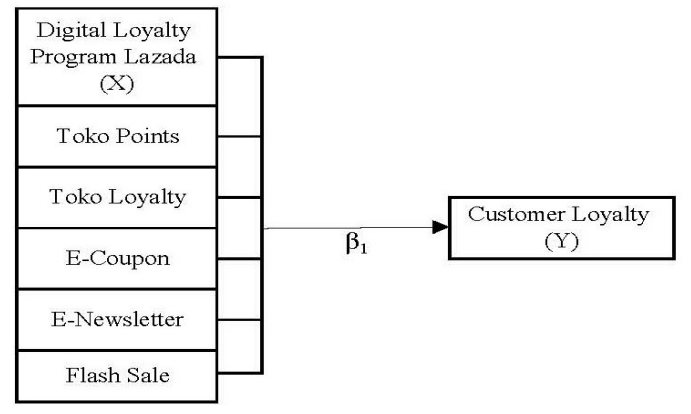

Figure 2 Direct Effect of Variable X on Variable Y

The regression equation in the second model:

$\mathrm{Y}=\beta_{0}+\beta_{1} \mathrm{X}$

Figure 3 provides diagram of the indirect impact of digital loyalty program (X) on customer loyalty (Y) mediated by consumer satisfaction (M). The test aims to predict the extent of customer satisfaction mediation on the value of Lazada digital loyalty programs for customer loyalty.

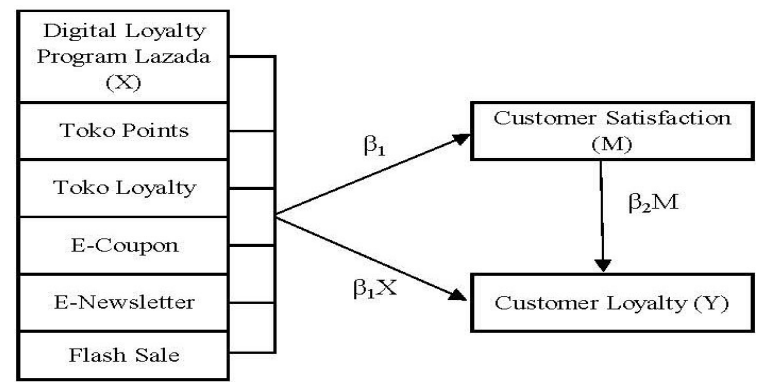

Figure 3 Indirect Influence of $\mathrm{X}$ on $\mathrm{Y}$ through $\mathrm{M}$ as Mediation 
The regression equation in the third model is:

$$
\mathrm{Y}=\beta_{0}+\beta_{1} \mathrm{X}+\beta_{2} \mathrm{M}
$$

When the effect of variable $\mathrm{X}$ on $\mathrm{Y}$, which was significant, becomes insignificant after inserting variable $\mathrm{M}$ into the regression equation model, it is considered that variable $\mathrm{M}$ testing criteria are declared as perfect mediation variables. On the other hand, when the insignificant effect of variable $\mathrm{X}$ on $\mathrm{Y}$ becomes significant after variable $\mathrm{M}$ is inserted into the regression equation model, variable $\mathrm{M}$ is declared as a partial mediation variable.

\section{RESULTS AND DISCUSSIONS}

From the model regression analysis as seen in Table 2, the significance value of all items in the digital loyalty program $(\mathrm{X})<0,05$. It means that the digital loyalty program $(\mathrm{X})$ affects the customer satisfaction (M) either individually/partially (t-test) or collectively/simultaneously ( $\mathrm{F}$ test). The magnitude of the influence can be seen in the R-squared value of 0,822 meaning that the digital loyalty program (X) affects customer satisfaction (M) certain factors outside of this report are impacted by $82,2 \%$ and the other $17,8 \%$.

The magnitude of the influence between each digital loyalty program on customer satisfaction can be seen in the correlation-Pearson value, in which Toko Points gives the most influence since it has a strong relationship and direction (positive) to customer satisfaction (Figure 4).

Based on data processing using SPSS program assistance, digital loyalty program (X) to customer satisfaction (M) obtains a constant coefficient value of 0,076 and a regression coefficient value of 0,90 , so the regression equation for the first model is:

$\mathrm{M}=\beta_{0}+\beta_{1} \mathrm{X}$

Customer satisfaction $=0,076+0,906$ digital loyalty program.

It can be concluded that the first criterion "independent variable (X) affects the variable that is suspected as a mediation variable (M)" to test the customer satisfaction variable (M) as the mediation variable is fulfilled.

The second model regression analysis, as seen in Table 3, shows the significance value of all items in the digital loyalty program variable $(X)<0,05$. It means the digital loyalty program variable $(\mathrm{X})$ affects the customer loyalty variable (Y) either individually/ partially (t-test) or collectively/simultaneously (F test). The significance of the influence can be seen in the R-squared value of 0,804 meaning that the digital loyalty program (X) affects customer loyalty (Y) certain factors outside of this research are affected by $80,4 \%$ and the remaining $19,6 \%$.

The significance of the impact between each digital loyalty program on customer loyalty can be seen in the correlation-Pearson value. E-coupon gives

Table 2 First Model Regression Test

\begin{tabular}{lcccccc}
\hline \multicolumn{1}{c}{ Var. } & Coeff. Std. & Corr. Pearson & t-Val & F-Val & R-Squared & Sig. \\
\hline DLP & 0,906 & & & & & 0,000 \\
Constant & 0,076 & & & & & \\
TP & 0,182 & 0,772 & 2,683 & & & 0,008 \\
TL & 0,250 & 0,678 & 4,560 & 97,064 & 0,822 & 0,000 \\
EC & 0,232 & 0,757 & 3,796 & & & 0,000 \\
EN & 0,189 & 0,717 & 3,183 & & & 0,002 \\
FS & 0,269 & 0,744 & 4,557 & & & 0,000 \\
\hline
\end{tabular}

Source: Data processed results 2021 (SPSS)

$\begin{array}{rlll}\text { Description : DLP } & =\text { Digital Loyalty Program } & \text { FS } & =\text { Flash Sale } \\ \text { TP } & =\text { Toko Points } & \text { EC } & =\text { E-Coupon } \\ \text { EN } & =\text { E-Newsletter } & \text { Coeff. Std. } & =\text { Coefficient Standard } \\ \text { TL } & =\text { Toko Loyalty } & \text { Corr. Pearson } & =\text { Correlation-Pearson }\end{array}$

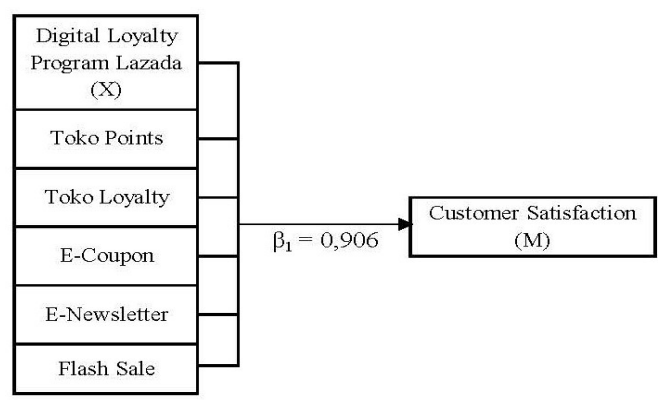

Figure 4 Mediation of Costumer Satisfaction from Digital Loyalty to Costumer Loyalty 
Table 3 Second Model Regression Test

\begin{tabular}{lcccccc}
\hline \multicolumn{1}{c}{ Var. } & Coeff. Std. & Corr. Pearson & t-Val & F-Val & R-Squared & Sig. \\
\hline DLP & 0,896 & & & & & 0,000 \\
Constant & 0,006 & & & & & \\
TP & 0,162 & 0,756 & 2,275 & & & 0,025 \\
TL & 0,206 & 0,645 & 3,570 & 85,981 & 0,804 & 0,001 \\
EC & 0,287 & 0,771 & 4,454 & & & 0,000 \\
EN & 0,219 & 0,724 & 3,503 & & & 0,001 \\
FS & 0,232 & 0,729 & 3,740 & & & 0,000 \\
\hline
\end{tabular}

Source: Data processed results 2021 (SPSS)

Description: DLP = Digital Loyalty Program

$$
\begin{aligned}
\mathrm{TP} & =\text { Toko Points } \\
\mathrm{EN} & =\text { E-Newsletter }
\end{aligned}
$$

\begin{tabular}{|c|c|c|}
\hline $\begin{aligned} \mathrm{TL} & =\text { Toko Loyal } \\
\mathrm{FS} & =\text { Flash Sale }\end{aligned}$ & $\begin{array}{l}\text { Coeff. Std. } \\
\text { Corr. Pearson }\end{array}$ & $\begin{array}{l}=\text { Coefficient Standard } \\
=\text { Correlation-Pearson }\end{array}$ \\
\hline
\end{tabular}

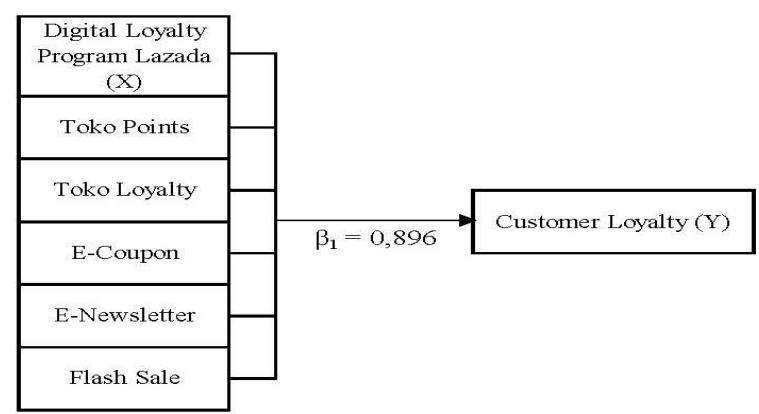

Figure 5 Relation of Digital Loyalty on Costumer Satisfatcion

Table 4 Third Model Regression Test

\begin{tabular}{lcccccc}
\hline \multicolumn{1}{c}{ Var. } & Coeff. Std. & Corr. Pearson & t-Val & F-Val & R-Squared & Sig. \\
\hline (Constant) & $-0,044$ & & & & & 0,000 \\
DLP & 0,322 & 0,896 & 4,015 & 378.600 & 0,875 & 0,000 \\
CS & 0,634 & 0,925 & 7,904 & & & 0,000 \\
\hline
\end{tabular}

Source: Data processed results 2021 (SPSS)

Description: DLP = Digital Loyalty Program

$\mathrm{CS}=$ Customer Satisfaction

$\begin{array}{ll}\text { Coeff. Std. } & =\text { Coefficient Standard } \\ \text { Corr. Pearson } & =\text { Correlation-Pearson }\end{array}$

the most influence since it has a strong relationship and direction (positive) to customer satisfaction.

Figure 5 shows that digital loyalty program (X) to customer loyalty (Y) obtains a constant coefficient value of 0,006 and a regression coefficient value of 0,896. Therefore, the regression equation for the first model is:

$\mathrm{M}=\beta_{0}+\beta_{1} \mathrm{X}$

Customer loyalty $=0,006+0,896$ digital loyalty program

It can be concluded that the second criterion "independent variable $(\mathrm{X})$ affects dependent variable $(\mathrm{Y})$ " to test the customer satisfaction variable (M) as the mediation variable is fulfilled. The third model regression analysis can be seen in Table 4. The importance of the digital loyalty program (X) and customer satisfaction $(\mathrm{M})<0,05$.
It shows that the digital loyalty program (X) and customer satisfaction (Y) affect the customer loyalty (Y) either individually/partially (t-test) or collectively/simultaneously (test F). The significant influence can be seen in the R-squared value 0,875 which means that the digital loyalty program $(\mathrm{X})$ and customer satisfaction (M) affect customer loyalty (Y) by $87,5 \%$ and the remaining $12,5 \%$ is influenced by other variables outside of the research.

Digital loyalty program (X) to customer loyalty (Y) obtains a constant coefficient value of $-0,044$. In addition, as seen in Figure 6, a regression coefficient value of digital loyalty program (X) is 0,322 and a coefficient value of customer satisfaction (M) is 0,634 . Thus, the regression equation for the first model is:

$\mathrm{Y}=\beta_{0}+\beta_{1} \mathrm{X}+\beta_{2} \mathrm{M}$

Customer loyalty $=-0,044+0,322$ digital loyalty program $+0,634$ customer satisfaction 


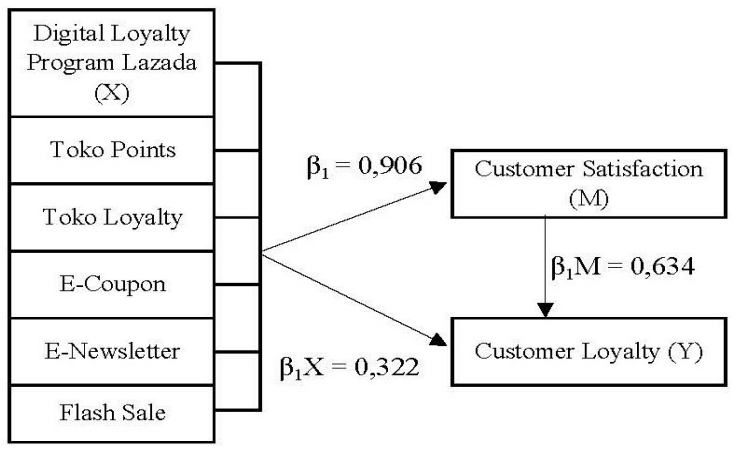

Figure 6 Relation of Digital Loyalty on Costumer Loyalty

Table 5 Hypothesis Testing

\begin{tabular}{lll}
\hline & \multicolumn{1}{c}{ Hypothesis } & \multicolumn{1}{c}{ Result } \\
\hline $\mathrm{H}_{1}$ & DLP significantly influences customer satisfaction & $\beta=0,906, \mathrm{Sig}=0,000<0,05$ \\
$\mathrm{H}_{1 \mathrm{a}}$ & TP significantly influences customer satisfaction & $\beta=0,182, \mathrm{Sig}=0,008<0,05$ \\
$\mathrm{H}_{1 \mathrm{~b}}$ & TLP significantly influences customer satisfaction & $\beta=0,250, \mathrm{Sig}=0,000<0,05$ \\
$\mathrm{H}_{1 \mathrm{c}}$ & EC significantly influences customer satisfaction & $\beta=0,232, \mathrm{Sig}=0,000<0,05$ \\
$\mathrm{H}_{1 \mathrm{~d}}$ & EN significantly influences customer satisfaction & $\beta=0,189, \mathrm{Sig}=0,002<0,05$ \\
$\mathrm{H}_{1 \mathrm{e}}$ & FS significantly influences customer satisfaction & $\beta=0,269, \mathrm{Sig}=0,000<0,05$ \\
$\mathrm{H}_{2}$ & DLP significantly influences customer loyalty & $\beta=0,896, \mathrm{Sig}=0,000<0,05$ \\
$\mathrm{H}_{2 \mathrm{a}}$ & TP significantly influences customer loyalty & $\beta=0,162, \mathrm{Sig}=0,025<0,05$ \\
$\mathrm{H}_{2 \mathrm{~b}}$ & TLP significantly influences customer loyalty & $\beta=0,206, \mathrm{Sig}=0,001<0,05$ \\
$\mathrm{H}_{2 \mathrm{c}}$ & EC significantly influences customer loyalty & $\beta=0,287, \mathrm{Sig}=0,000<0,05$ \\
$\mathrm{H}_{2 \mathrm{~d}}$ & EN significantly influences customer loyalty & $\beta=0,219, \mathrm{Sig}=0,000<0,01$ \\
$\mathrm{H}_{2 \mathrm{e}}$ & FS significantly influences customer loyalty & $\beta=0,232, \mathrm{Sig}=0,000<0,05$ \\
$\mathrm{H}_{3}$ & CS significantly influences customer loyalty & $\beta=0,634, \mathrm{Sig}=0,000<0,05$ \\
$\mathrm{H}_{4}$ & CS mediates the relationship between loyalty programs & The standardized value of beta coefficients obtained \\
& and customer loyalty & by the digital loyalty program (X) weakened or \\
& & decreased by $0,322<0,896$ with the addition of \\
\hline
\end{tabular}

Source: Researcher (2021)

It can be concluded that standardized coefficients beta value obtained variable digital loyalty program (X) weakened or decreased $0,322<0,896$ with the addition of customer satisfaction $(\mathrm{M})$. It reveals that customer satisfaction (M) has a mediation role to digital loyalty program (X) and customer loyalty (Y). In addition, the third criteria to test the customer satisfaction (M) as a mediation variable is fulfilled. Table 5 shows the results of each hypothesis test.

\section{CONCLUSIONS}

It is interesting to see from the outcomes that the variables of the digital loyalty program (along with all Lazada loyalty programs) influence consumer satisfaction and Lazada customer loyalty. Digital loyalty program that has the most influence on customer satisfaction is Toko Points, whereas the program that has the most influence on customer loyalty is e-coupon. The result is alleged because Toko Points gives benefits to Lazada users by redeeming points to get attractive coupons such as Cashback, free shipping, and other discounts that make Lazada customers feel satisfied with the benefits earned until finally loyal to Lazada. The customer satisfaction serves as a mediation function that explains that the digital loyalty program indirectly affects customer loyalty through Lazada customer satisfaction.

In previous research, the relationship between customer satisfaction and customer loyalty has been proven by Iddrisu et al. (2015) who concentrate on how the importance of the digital loyalty system on consumer satisfaction and show that customer loyalty is directly linked to customer loyalty. Visitors, as well as customers, is proven loyal to Lazada website based on the results and calculation of data on visitor loyalty that show drastic increase. This is in common with current research that the variables studied have an influential relationship with each other. Based on the results, it is considered that management can take steps to keep the current promotion, improve, or see promotions or programs that are less efficient in 
attracting customers' attention.

Research limitation in sampling questionnaires shows that not all respondents know Lazada since some of them shop at Shopee, Blibli, Bukalapak, and so on. For Lazada customers, some people are unfamiliar with loyalty programs since too many promotional activities and additional services make it increasingly difficult for customers to understand the forms of promotion resulting in the transfer of customers to competitors. It is recommended that future research with similar topic add more data to produce more prominent value. In addition, it is advisable to add other variables such as trusts, brand images, and other considerations that may have a substantial influence on consumer satisfaction and loyalty to customers.

\section{REFERENCES}

Alnawas, I. \& Hemsley-Brown, J. (2018). The differential effect of cognitive and emotional elements of experience quality on the customer-service provider's relationship. International Journal of Retail and Distribution Management, 46(2), 125147. https://doi.org/10.1108/IJRDM-03-2017-0058.

Alsaggaf, M. A. \& Althonayan, A. (2018). An empirical investigation of customer intentions influenced by service quality using the mediation of emotional and cognitive responses. Journal of Enterprise Information Management, 31(1), 194-223. https:// doi.org/10.1108/JEIM-04-2017-0048.

Bijmolt, T. H. A., Krafft, M., Sese, F. J., \& Viswanathan, V. (2017). Multi-tier loyalty programs to stimulate customer engagement. In R. W. Palmatier, V. Kumar, \& C. M. Harmeling (Eds.). Customer Engagement Marketing (pp. 119-139). Springer International Publishing. https://doi.org/10.1007/978-3-31961985-9 6.

Breugelmans, E., Bijmolt, T. H. A., Zhang, J., Basso, L. J., Dorotic, M., Kopalle, P., ... Wünderlich, N. V. (2015). Advancing research on loyalty programs: A future research agenda. Marketing Letters, 26, 127139. https://doi.org/10.1007/s11002-014-9311-4.

Breugelmans, E. \& Liu-Thompkins, Y. (2017). The effect of loyalty program expiration policy on consumer behavior. Marketing Letters, 28, 537-550. https:// doi.org/10.1007/s11002-017-9438-1.

Bruneau, V., Swaen, V., \& Zidda, P. (2018). Are loyalty program members really engaged? Measuring customer engagement with loyalty programs. Journal of Business Research, 91, 144-158. https:// doi.org/10.1016/j.jbusres.2018.06.002.

Hassan, R. S., Nawaz, A., Lashari, M. N., \& Zafar, F. (2015). Effect of customer relationship management on customer satisfaction. Procedia Economics and Finance, 23, 563-567. https://doi.org/10.1016/ s2212-5671(15)00513-4.

Iddrisu, A., Nooni, I., \& Mensah, W. (2015). Assessing the impact of service quality on customer loyalty: A case study of the cellular industry of Ghana. British Journal of Marketing Studies, 3(6), 15-30.
Ieva, M. \& Ziliani, C. (2017). Towards digital loyalty programs: Insights from customer medium preference segmentation. International Journal of Retail and Distribution Management, 45(2), 195210. https://doi.org/10.1108/IJRDM-01-2016-0012.

Iglesias, O., Markovic, S., Bagherzadeh, M., \& Singh, J. J. (2020). Co-creation: A key link between corporate social responsibility, customer trust, and customer loyalty. Journal of Business Ethics, 163, 151-166. https://doi.org/10.1007/s10551-018-4015-y.

Khan, A. R. \& Islam, M. A. (2017). The impact of digital marketing on increasing customer loyalty: A study on Dhaka City, Bangladesh. International Journal of Economics, Commerce and Management, 5(4), 521528. https://ssrn.com/abstract=2989948.

Kotler, P. (2018). Why broadened marketing has enriched marketing. AMS Review, 8, 20-22. https://doi. org/10.1007/s13162-018-0112-4.

Li, C. Y. (2018). Consumer behavior in switching between membership cards and mobile applications: The case of Starbucks. Computers in Human Behavior, 84, 171-184. https://doi.org/10.1016/j.chb.2017.12.042.

Lim, S. \& Lee, B. (2015). Loyalty programs and dynamic consumer preference in online markets. Decision Support Systems, 78, 104-112. https://doi. org/10.1016/j.dss.2015.05.008.

Liu, F., Xiao, B., Lim, E. T. K., \& Tan, C. W. (2017). Investigating the impact of gender differences on alleviating distrust via electronic word-of-mouth. Industrial Management and Data Systems, 117(3), 620-642. https://doi.org/10.1108/IMDS-04-20160150

Magatef, S. G. \& Tomalieh, E. F. (2015). The impact of customer loyalty programs on customer retention. International Journal of Business and Social Science, 6(8), 78-93.

Mainardes, E. W., Rosa, C. A. de M., \& Nossa, S. N. (2020). Omnichannel strategy and customer loyalty in banking. International Journal of Bank Marketing, 38(4), 799-822. https://doi.org/10.1108/IJBM-072019-0272.

Nobre, H. \& Rodrigues, C. (2018). Loyalty programs in the pharmaceutical retail: The impact of a network loyalty program on the pharmacy loyalty. International Journal of Business Excellence, 14(4), 454-469. https://doi.org/10.1504/IJBEX.2018.090312.

Ofori, K. S., Boakye, K., \& Narteh, B. (2018). Factors influencing consumer loyalty towards $3 \mathrm{G}$ mobile data service providers: Evidence from Ghana. Total Quality Management and Business Excellence, 29(5-6), 580-598. https://doi.org/10.1080/14783363 .2016 .1219654 .

Pereira, H. G., de Fátima Salgueiro, M., \& Rita, P. (2017). Online determinants of e-customer satisfaction: Application to website purchases in tourism. Service Business, 11, 375-403. https://doi.org/10.1007/ s11628-016-0313-6.

Schirmer, N., Ringle, C. M., Gudergan, S. P., \& Feistel, M. S. G. (2018). The link between customer satisfaction and loyalty: The moderating role of customer characteristics. Journal of Strategic Marketing, 
26(4), 298-317. https://doi.org/10.1080/096525 4X.2016.1240214.

Seckler, M., Heinz, S., Forde, S., Tuch, A. N., \& Opwis, K. (2015). Trust and distrust on the web: User experiences and website characteristics. Computers in Human Behavior, 45, 39-50. https://doi. org/10.1016/j.chb.2014.11.064.

Sekaran, U. \& Bougie, R. (2016). Research Methods for Business a Skill-Bulding Approach ( $7^{\text {th }}$ Ed.). New York: Wiley.

Sungirirai, A., Chiguvi, D., \& Sungirirai, L. (2017). The effect of customer loyalty programs on customer satisfaction in the mobile telecommunications sector in Botswana. International Journal of Science and Research, 6(2), 1815-1824. https:// www.ijsr.net/search_index_results_paperid. php?id=ART20164139.

Tahal, R. (2014). Loyalty programs in e-commerce and their perception by the young adult internet population. Central European Business Review, 3(2), 7-13. https://doi.org/10.18267/j.cebr.79.

Tjiptono, F. \& Chandra, G. (2011). Service, Quality dan Satisfaction ( $4^{\text {th }}$ Ed.). Yogyakarta: Andi Offset

Trivedi, S. K. \& Yadav, M. (2020). Repurchase intentions in Y generation: Mediation of trust and e-satisfaction.
Marketing Intelligence and Planning, 38(4), 401415. https://doi.org/10.1108/MIP-02-2019-0072.

Vesel, P. \& Zabkar, V. (2009). Managing customer loyalty through the mediating role of satisfaction in the DIY retail loyalty program. Journal of Retailing and Consumer Services, 16(5), 396-406. https://doi. org/10.1016/j.jretconser.2009.05.002.

Vildová, E., Martinčik, D., Tlučhoř, J., \& Jakubíková, D. (2015). Measuring customer satisfaction and loyalty in spa companies. E a M: Ekonomie a Management, 18(1), 151-168. https://doi.org/10.15240/ tul/001/2015-1-012.

Watson, G. F., Beck, J. T., Henderson, C. M., \& Palmatier, R. W. (2015). Building, measuring, and profiting from customer loyalty. Journal of the Academy of Marketing Science, 43, 790-825. https://doi. org/10.1007/s11747-015-0439-4.

Zakaria, I., Rahman, B. A., Othman, A. K., Yunus, N. A. M., Dzulkipli, M. R., \& Osman., M. A. F. (2014). The relationship between loyalty program, customer satisfaction and customer loyalty in retail industry: A case study. Procedia - Social and Behavioral Sciences, 129, 23-30. https://doi.org/10.1016/j. sbspro.2014.03.643. 